\title{
Persistence and Creativity: EmersonWRITES Celebrates 11 Years with Young Poets and Writers of Boston
}

\section{Introduction by Mary Kovaleski Byrnes and Livia Meneghin}

Essays and poems by Rejeila Firmin, Star Igbinosa, Ebony Smith, Essence Smith, Winter Jones, Yaritza Santana, Paola Ruiz Manrique, Madison Lucchesi, and Zaryah Qareeb

EmersonWRITES is a free creative writing program for students in Greater Boston public and charter schools, co-sponsored by the Offices of Enrollment and Student Success and the First-Year Writing Program at Emerson College. EmersonWRITES is guided by the principle that writing is essential to intellectual engagement, self-representation, and access to opportunity. Students in the EmersonWRITES program engage in college-style creative writing classes on campus at Emerson College, where courses are structured to build writing and critical thinking and to guide students toward negotiating a range of writing genres and rhetorical situations. EmersonWRITES seeks to foster individual voice and engagement with the world through the written word.

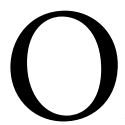

$\mathrm{n}$ a Sunday afternoon in February, EmersonWRITES hosts a celebration of creative writing for our local high school students. While these celebrations have occurred for over a decade, when we reflect on the last eleven celebrations, our minds are drawn to the stark contrasts between February 2020, when we gathered with over 100 people and shared a meal in a boisterous auditorium, and this past February in 2021, when that same supportive group was seen through a screen of rectangles. Like so many aspects of our lives, our community writing program had to adjust to the demands of this ruthless virus. In recognition of all losses of this past year, it may seem insensitive to seek out celebration. However, it would be a mistake to view our students and teachers as anything less than triumphant in the face of one of the biggest challenges any of us will ever encounter.

Prior to this year, when our courses shifted to a virtual model, the EmersonWRITES program offered free creative writing workshops and college-access programming to students in Boston public and charter schools on Emerson College's campus on Saturday mornings. Our students come from all over the city and identify as African American, Asian, Black, and Latinx; many speak multiple languages including Arabic, Haitian Creole, Spanish, and Somali. As the program's mission is grounded in pedagogies of anti-racism and multilingualism, it's important to recognize how teachers and students move within and against the challenges presented in our city and in our greater society from sexism to police brutality to ICE raids in their 
neighborhoods. In some ways, the work of the program was daunting and riddled with obstacles even before the pandemic hit, no matter how enriching the subject matter and mentoring, the friendships made, or the free lunch offered. Our students come from various neighborhoods on the $\mathrm{T}$, which was often under construction or generally slow; the weather between October and February could be described as brutal; and our program runs on a weekend. Many of our students' lives are full of responsibilities and challenges that would feel overwhelming to any adult, let alone a teenager. Teachers juggled the demands of graduate school and work as Boston's exorbitant and continuously rising cost of living pushed teachers' housing options ever further from Emerson's downtown campus. And yet, even in the throes of the pandemic, students and teachers persisted.

Out of the eleven years of student work published in our annual anthology, SPINE, we have gathered nine pieces below. Some of the older pieces include Rejeila Firmin's essay “A Flower Bloomed in a Dark Room," which was part of a grant-awarded project that explored intergenerational narratives in families. There's Winter Jones's contrapuntal poem "Butterfly," which uses extended metaphor to connect ideas about place, identity, and strength to prompt multiple readings. Poet Yaritza Santana wrote "An Intruder," which uses narrative and code-meshing to share her commentary on the realities of immigration. Another poem, "Ode 2 Pac," written in 2017 by Essence Smith, mourns the continuous loss of Black lives to murder by police. Four years later, her twin sister Ebony Smith wrote "Millennial Voices Debate their Ancestors," a poem that embodies a sense of weariness in the face of such endless injustice. And there's Paola Andrea Ruiz Manrique's poem, "A Letter to My Neighbor," which reflects on the demands of being a teenager in today's society. In addition, there are three texts from this past year's virtual iteration of the program: sophomore Madison Lucchesi's poem "Salutary Neglect" responds to the January 2021 insurrection on the Capitol building; junior Zaryah Qareeb's memoir, "Wrinkles," is a reflection on self-criticism and mother-daughter relationships; and junior Star Igbinosa captured the sudden emptiness of pandemic life for teenagers in her poem "Dreams with No Substance with No Life."

When the students took the spotlight during our virtual Zoom showcase this past February and read the words from these and other stories and poems, they affirmed that their creativity and their labor with the written word would be a beacon for them and their audiences during the toughest of times. With the country slowly moving forward out of this difficult year, EmersonWRITES will continue to reshape and adjust to meet our students' needs and grow this community in ways we never anticipated before the pandemic. Knowing how much heart and talent these writers have brought to the program for over a decade, we look forward to reading more inspiring work from the creative and resilient teens in Boston for many years to come.

\section{"A Flower Bloomed in a Dark Room" by Rejeila Firmin}

I remember getting forehead wrinkles that I thought would be permanent from the amount of stank looks I gave that day. The cool breeze relaxed the humid air like a 
shoulder massage as I popped my headphones in, eyes closed. The city felt more and more like home with each passing block. I gazed at the corner stores, barber shops, and beauty supply stores, finally acknowledging their cultural significance. I thought about all of the cookout stories that took place there, like the one my uncle told that made us laugh until our stomachs hurt. And that's when it happened. Perfect timing, really. My playlist ended and Spotify automatically played "m.A.A.d city" by none other than Kendrick Lamar.

Kendrick Lamar Duckworth, 32. Born and raised in Compton. To some, he's an opportunity. To others, he's a rapper. To me, he's a reflection. What makes Kendrick so different from the rest? He is a lyricist. He puts words together like art. His delivery is a mixture of cultural metaphors, double entendres, history lessons, onomatopoeia, tongue-twisters, and modern-day allusions. He spits the kind of lyrics that make you stop and run the whole track back. Kendrick is on a different type of time.

Every set of lyrics is a poem. Every poem becomes a song. Every song tells a story. Every story carries a message. Every message pertains to the Black community in some way. I listen to Kendrick because he indulges in Black culture. He is Black, just like me. A fact as simple as that amplifies to speak volumes. His albums became learning opportunities for me, a chance for me to relate to someone for once.

Last year, I read If Beale Street Could Talk by James Baldwin and underwent a plethora of emotions. In the midst of all the tears, laughter, pride, and enchantment, I discovered a connection between Baldwin's novel and Kendrick Lamar's "m.A.A.d city." Baldwin's romance novel is told from the perspective of a young Black woman throughout her journey of discovering the gutting reality of what it means to be a Black man in America. The father of her unborn child, lifelong companion, and first love acts as her catalyst for discovery. The characters truly construct and drive the story. The purpose of the novel comes in the fact that the most complex character was the setting.

Throughout the novel, Baldwin gave the setting the ability to influence the characters, the ability to feel sorrow and inflict that sorrow upon others. Baldwin does this to pay homage to the communal bond between members of the minority. Baldwin's critics saw the novel as utopian, rather than providing an alternate ending to a common story. There is power in being Black, which is something that Baldwin's critics failed to realize, hence the subliminal comments on Baldwin's optimism. And that's where I drew the connection: optimism.

In "m.A.A.d city", Kendrick Lamar says, "Hope euphoria can slow dance with society." In an interview, Kendrick revealed, "So I always wanted to put that type of vulnerability out there where I have always been this dreamer. I am a realist, but at the same time what separates me from the rest of my homeboys is the fact that I can dream of this hope." Kendrick is aware of the dangers of being a dreamer, as is Baldwin who said, "Every poet is an optimist...but on the way to that optimism 'you have to reach a certain level of despair to deal with your life at all."

It takes courage to dream as a person of color with societal limits and expectations. But Baldwin wrote for the minority anyway, and Kendrick Lamar raps for the 
generations after him. Kendrick's optimism and pride are seemingly contagious, and I find it hard not to gain insight and inspiration from his words.

So back to that story that my uncle told. Nothing special. Honestly, I don't even remember it that well. He was a young Haitian immigrant, starting trouble outside of the laundromat. He tried to act tough with some older kids and they ran after him and my dad (who was carrying two big-ass laundry bags) until one of them ran right into a pole. Now, yes, the story itself is funny...but that's not what I'm getting at. It's the way we all laughed (or some of us got up and ran) and shared our happiness with each other. At that moment, our connection felt multidimensional, bigger than us. That's what optimism means to me.

\section{"Dreams with No Substance with No Life" by Star Igbinosa}

Without Free Enterprise

I've planted my body on this cushioned chair

In this room so bare

Neglecting the many deep green spiraling stems

Flourishing from my indoor garden of flower paradise

This large white canvas sits in front of me

$$
\text { Mocking me }
$$

Alluding that I will never be free of all its glorious natural space

Is this space really natural?

The focus is now on my crown

In the sun's eyes my kinky curls reach for limitless skies and radiate self-restoration

In its golden-brown eyes, my trauma was nothing more than a Compromise

Irreplaceable pieces of me snatched by this merciless life

With no regards as to how I would make it out in time

Shrinkage

My crown begins to decrease in size until the not-so-natural space devours it

Whole?

\section{No}

Just enough to leave me feeling empty

Wandering aimlessly in a world that requires nothing but direction and paper

How am I supposed to conquer those systems if my self has Dissociated

Far from the point of restoration?

So now I float above the bare room

Of flower paradise

With the cushioned chair that my black body cannot escape from

Staring at the white canvas

With half of my soul gone 


\section{"Millennial Voices Debate their Ancestors" by Ebony Smith}

Martin Luther King wasn't even mainstream

With a 75\% disapproval rating in his lifetime.

This is useless.

Stop making me the spokesperson, to be meticulous, perfect, to say the right things to the wrong crowds.

Why are you forcing me to be politically aware?

Like I don't see them walking on the other side of the street.

Like I don't hear the underlying tone

in the white women's voice, telling me that I need to buy something, because it's illegal to loiter.

How can I forget that I'm Black when they remind me every day?

I don't have an opinion to share.

I don't have a vote to cast.

I don't follow any social activists to repost.

Where's my childhood?

Did it get lost in my kinky hair?

Is my skin too dark for you to find it?

\section{"Ode 2 Pac" by Essence Smith}

Excuse me, but it seems y'all still haven't learned it's been exactly 20 years since my demise but even from the shimmering, azure heaven above Ms. Lady Liberty still cannot see all the people want is the joy of being free they want 2 live in glee without having 2 flee every time the red and blue lights shadow the streets Liberty and Justice still hanging and banging on my homeboys, doing us dirty 
like we are not supposed 2 make noise

the cops still carrying their glocks blasting their rounds of blazing fiery

bullets into us

\section{CLICK}

\section{CLOCK}

\section{BANG}

\section{SHOT}

when will America wake up

it's like the alarm clock never went off

do they not hear our screaming?

another brother that looks like me

lying in the dirt

lifeless

his crimson blood stained his ebony skin

the media will only show his story once

unless he was a criminal

or a Thug

or had a picture of himself, posing with a gun

because then it will seem like he deserved what was handed to him

like he was living in the fast lane, but karma still caught up

but

who asked the cop to play God? now the family is dressed in black

gathered in the church, trying to remember someone who is already

forgotten

trying to get back

the one they lost

but even as the days pass

the mass of Black brothers and sisters

stand together

hand in hand

their strong voices shouting

"NO JUSTICE, NO PEACE"

to fight against the ones who give out

cruel and unusual punishments

hope for the youth and the future may seem lost

but we are not hopeless

the fervent flames are still burning in our eyes

gasoline flows deep in our bloodstream

all we need is a match

to set the crooked system in flames 


\section{"Butterfly" by Winter Jones}

Breathe in. But I can't...

Breathe out. I can't understand why.

Move on. You won't do it, no balls.

They didn't mean it But they did
maybe they did mean it.

It's suffocating. It's gut wrenching

to understand to think

that words deeply embedded

with full trust, with genuine speech

With (un)requited love, with deep respect

with seemingly tantalizing truths that words can be so fragile,

can dance through the air and shatter at the slightest bit of doubt

oh so violently oh so crippling

that they immobilize. that they disenchant.

That they lose their dance They lose their purpose.

$$
\begin{aligned}
& \text { They drop the oils } \\
& \text { of sorrow, } \\
& \text { of self-doubt, } \\
& \text { of trust issues, } \\
& \text { of abhorrence, } \\
& \text { unintentionally. }
\end{aligned}
$$

Stopping the butterfly from doing her own dance.

Stopping the butterfly from knowing her purpose. 


\section{"An Intruder" by Yaritza Santana}

It's the Caribbean Sea that carries me home

On June 16, 2003, at Clinica Peravia in Bani

My culture is rich and its people diverse

The blood of my ancestors courses through my veins

You say that makes me an immigrant

I say that makes us one and the same

You are so quick to toss us aside

But you love our food, our music, and you study our language

But you don't know anything about our culture

So here is a quick lesson:

Mis ancestros levantan los puños debajo de nuestra Bandera

El Rojo representa la sangre de mis ancestros,

En la lucha por la Independencia.

El azul representa el cielo que se encuentra sobre nuestras cabezas.

Y simboliza a Dios y la protección que él nos da.

El Blanco representa la Paz, no rendición.

The tongue that I speak may be foreign and cause you fear

When I come knocking on your door

But it's because you can't decipher the code

You weren't meant to hear

I came to your country for the education at the age of two

My tongue became my enemy

As it didn't speak like you

I had to train it so that you could understand me more

Me adapte a tu idioma

But by doing so I chipped away at my tongue

And while it started to speak like yours it also bled,

It was never my intention to change who I am

But I had to learn to adapt if I wanted to rise

But assimilation is never what $\mathrm{I}$ had in mind

You seek to tie us down like a dog on a leash,

But I won't roll over so don't try to make me bark before I speak.

Don't try to give me a treat so I'll behave.

I don't follow your rules and I'll happily bite back any day.

You pick at my skin because it's mapped out,

But I bring the route of my home with me and an eraser won't brush it out. 


\section{"A Letter to My Neighbor" by Paola Ruiz Manrique}

I am the neighbor of such a strong person.

I see what you go through every day.

I have seen how broken you were left. The pain you carry.

The way this society celebrates disorientation.

And the way it crashes you into panic and anxiety.

Silencing it with melodies of Romeo Santos and Drake.

Although you may see yourself as weak for being expressive,

I see you as strong because I lack the ability.

I have seen how much you searched for an anecdote to your hurt.

And through your pain you educate me.

Strength is a quality you have taught me.

You taught me wild love.

You taught me selflessness when you pose in front of

the Christmas tree to see a smile arise on my face.

You taught me to dedicate my time through hours on facetime.

You taught me to listen.

You taught me to be fearless when expressing myself.

You taught me how much I need to be cared for,

and how much I need to care for you.

You taught me strength.

I fantasize of being as strong as you are.

I see the way cultures clash and the segregation

in the way we pursue our daily life.

It leads back to disorientation.

Trying to attune your family traditions

with the American lifestyles of your teachers.

Your Salvadorian curls reshaping into waves

betraying your documentation.

Afraid to miss any more days of school

because your parents will end up in a court duel.

But school is teaching me to discriminate my own people.

You taught me to perform Maluma concerts in the hallways.

You taught me to enunciate parce instead of dude.

You taught me what strength is.

But I also find myself and you seeking love to refuel us of that strength

A fierce love

A wild love

A selfless love.

An expressive love. 


\section{"Salutary Neglect" by Madison Lucchesi}

the act of a government turning a blind eye to the actions of its citizens

When the Black Lives Matter movement marches through Chicago

Join them or close your eyes, open your ears

Absorb the mosaics of pain and then act on it

Remember your manners

When you see a woman in a hijab at the grocery store

For her first amendment right is not a punchline

Take your personal beliefs and throw them in a dumpster fire

If you'd raise a sign against

Free healthcare and a woman's choice

Welcome your neighbors into your home

That means the immigrants too

For your blood is part immigrant

Cover your arrogance in glitter and rhinestones

Put the funding for Straight Pride in a rainbow box

Gift it to the LGBTQ+ community

But do not turn your cheek

When the president of a leading nation

Encourages his supporters to terrorize a federal building

This is not a time for silence

It is a time for screaming since

Speaking has been overlooked for centuries

We demand

To be given the

Tools to prosper

And to truly have

Life, liberty, and

The pursuit of happiness 


\section{"Wrinkles" by Zaryah Qareeb}

Her hand picks up the bulky metallic machine raging with hot air against the flimsy ironing board. I sit there studying the atmosphere around her, as she presses the steam iron onto the fabric with much determination. My eyes follow the trail of her arm, moving back and forth like a pendulum ball. "I hate wrinkled shirts," my mother murmurs.

She rushes, listening to the sound of the ticking clock taunting her. She corrects my lopsided pigtails and helps me to put on my black leather shoes. She stops to inspect me head to toe before leaving for the event. I can't recall the purpose of this event or why I was there. All I remember that day was my mother speaking highly of me and adults praising me in return. At the time, I never understood why she constantly emphasized looking polished. All I knew was that being close to perfect made Mom happy.

Growing up, Mom's motto in life was to always be prepared for anything, at any moment; "Those who prepare to face the unexpected, are the ones who succeed." This sentence echoed in my head as she buttoned up my shirt, dressing me up as if I were a doll sitting in the front window of a toy store.

You should always look presentable and be polite to make a good impression on others. Individuals with class must never wear a wrinkled shirt to convey the wrong message. A youthful white button up blouse will make you stand out amongst the rest. I was a representative of my family, and a symbol of my mother's hard work. Therefore, I took everything she said to heart; I desired her approval.

I began associating wrinkles with failure. One curve of a fold meant I failed. I failed to prepare myself for the day and for the opportunities ahead. Thinking about failing scared me, but the idea of disappointing my mother frightened me most.

As I grew older, I despised how time-consuming smoothing out my wrinkles was. Every second of going back and forth, thundering thoughts of disappointing my mother shook me.

One morning I forgot to iron my shirt. Looking down and seeing small creases on my clothing disturbed me. I felt as if everything depended on this shirt. I tried smoothing it out with my hands, but it didn't work. These wrinkles were a physical representation of my flaws. My guilt and shame magnified the longer I dwelled on it.

During moments like this, I pictured what younger me would say. I could see her face look up at me with eyes of confusion as the words "it's just a shirt" fall out between her lips. Younger me would be upset that I let little things like this make me feel like a failure. She would be disappointed that I put pressure on myself to be perfect all the time. I was always seeking approval from others but never from her.

In the end she was right, it was just a shirt, pieces of fabrics sewn together to create a whole. I remind myself that I'm not defined by it and it does not represent me as an individual. Giving up on the idea of being "perfect" made me feel renewed. Eventually, I found beauty in my wrinkles. 


\section{Author Bios}

Mary Kovaleski Byrnes is a co-founder and Program Director of EmersonWRITES and Senior Lecturer in the Writing, Literature, and Publishing Department at Emerson College. She is the author of a book of poems, So Long the Sky, and her work has appeared in Best of the Net, The Boston Globe, Guernica, Borderlands: Texas Poetry Review, and more.

Livia Meneghin is the EmersonWRITES Program Coordinator and writing instructor at Emerson College. She is the author of the chapbook Honey in My Hair. Her individual poems and reviews have found homes in The Academy of American Poets, Entropy Magazine, Tinderbox, Whale Road Review, and elsewhere. She earned her MFA in Poetry at Emerson in Spring 2021.

Rejeila Firmin is a Black female writer and student at Emerson College. She is passionate about music, activism, and photography. Also known as Wordsbyrei, she has a blog and an Instagram account dedicated to sharing her writing. She participated in EmersonWRITES in her last two years of high school.

Star Igbinosa is a junior at the Academy of the Pacific Rim Charter Public School and has seriously enjoyed being able to write in ways she never has before. Her love for being able to read the works of so many talented young artists like herself runs deep. Star's favorite foods are plantains and avocados. She can't wait for what the future has in store.

Winter Jones, as a newly admitted student to Simmons University and recipient of acceptances to schools such as Spelman College and Emerson College, hopes to find plenty of opportunities like what EmersonWRITES offered. Outside of her time writing, Winter plays video games, builds her connections, and actively searches for more opportunities.

Madison Lucchesi is a sophomore at Revere High School where she leads the Feminist Empowerment Movement and the Inclusive Opportunity Club. Her writing can be found in Teen Blurb Magazine and on Instagram @eclipsingentries.

Zaryah Qareeb is a visual artist who recently discovered her passion for creative writing. Many of her works contain screenplays and short stories. Her interests include watching films, baking vegan snacks, and playing with her cat, Star.

Paola Ruiz Manrique grew up in East Boston and was raised by Colombian parents. She is a senior at East Boston High School. Next year she will attend college and hopes to double major in English and Communications and Media to further pursue her passion for writing.

Yaritza Santana is currently a senior at Boston Prep, and this is her third and final year at EmersonWRITES. She loves to do writing in her free time and is going to pur- 
sue screenwriting in college. Sidenote: she also loves streaming the Marvel series with her friends on Disney+.

Ebony Smith is a current undergraduate at Harvard College. She plans to concentrate in Government with a secondary in History \& Literature. She has furthered her creative writing skills as an Editorial Writer for The Crimson journal at Harvard, and by starting up her own personal blog, titled "Black Girl Thoughts". Her sole purpose in writing remains: to address the racial inequities in this country through art.

Essence Smith is an upcoming sophomore at Trinity College double majoring in Political Science and History. At Trinity, Essence is involved in Trinity College Black Women's Organization, CONNPIRG, and Habitat for Humanity. In addition, Essence works in the Admissions Office and helps welcome incoming freshmen classes. 